Jurnal MAKSIPRENEUR, Vol. IV, No. 1, 2014, hal. 116 - 138

\title{
PENGEMBANGAN MODEL TRANSPORTASI KOTA DALAM MENGHADAPI TANTANGAN AGLOMERASI KOTA
}

\author{
Teguh Budi Prasetya, M Si.(teguhbudiprasetya@gmail.com) \\ Fisipol Universitas Proklamasi 45 Yogyakarta \\ DR-Ing. Ir. WINARNA, MA (winarna@yahoo.com) \\ Fakultas Arsitektur dan Desain UKDW
}

\begin{abstract}
Agglomeration cities not only cause physical problems and instrumental, but also cause problems in the implementation of urban transport. Existing institutional reality no longer able to provide transport services across the city, whose scope is in the surrounding area.

This paper sourced on the results of the first study of two years of research, Based on the results of previous studies, coupled with best transportation practices of Singapore and Bogotta, then drafted Urban Transport Model. A model that can address the challenges of the city agglomeration

Four cities sampled (Jakarta, Yogyakarta, Semarang and Cilacap) seen that every city has its own challenges. Institutional existing transportation is basically in the form of the city's response to answer the challenge. Commitment of all stakeholders will largely determine the success of institutional development.
\end{abstract}

Key words: agglomeration, public-transport institution,political commitment

\section{PENDAHULUAN}

Sesuai amanat UU No 32 tahun 2004 tentang Pemerintahan Daerah, dimana titik pusat otonomi daerah adalah Kabupaten/Kota, maka Sistem Transportasi Kota menjadi tanggung jawab Pemerintah Kabupaten/Kota. Pemerintah Kabupaten/Kota diberi kewenangan untuk merencanakan, mendanai, menggali dana serta menyelenggarakan transportasi kota sesuai dengan kebutuhan yang dihadapinya.

Atas dasar itu, maka Pemerintah Kabupaten/Kota membentuk institusi-institusi yang bertanggung-jawab mengelola sistem transportasi kota. Badan Perencana Pembangunan Daerah (Bappeda), Dinas Perhubungan, Dinas Pekerjaan Umum/ Prasarana Wilayah, dan Kepolisian Daerah adalah institusi-isntitusi daerah yang lazimnya menangani transportasi kota secara sektoral (Balitbang Dephub:2009). 
Bebeberapa nomenklatur institusi pengelola transportasi kota yang biasa dibentuk adalah Sub Dinas Jalan Raya, Kereta Api dan Angkutan Sungai Danau dan Perairan yang dibentuk diberbagai daerah (Balitbang Dephub:2009).

Hampir semua Pemerintah Kabupaten/Kota di Indonesia umumnya sudah menaruh perhatian serius atas transportasi kota. Selain pembentukan kelembagaan, mereka juga mengalokasikan anggaran besar pada sektor yang makin lama makin membutuhkan penanganan serius ini. Namun sayangnya semua itu terasa belum memadai, manakala institusi itu dihadapkan dengan realitas pertumbuhan kota (aglomerasi) yang amat pesat. Ketika aglomerasi terjadi, kota berkembang melintasi batas-batas wilayah administratif, dan merambah wilayah-wilayah administratif di sekitarnya. Pada saat seperti itulah institusi transportasi kota konvensional akan terbentur dengan keterbatasan kewenangan dan administratif transportasi kota.

Di sisi lain, regulasi transportasi kota yang masih terpisah secara sektoral berdampak pada lambatnya sinergi antar berbagai moda transportasi yang memiliki regulator berbeda dan terpisah. Akibatnya adalah buruknya kordinasi antar sektor transportasi kota.

Dalam situasi seperti itu, model kelembagaan transportasi kota konvensional berpotensi gagal memenuhi tuntutan. Hal itu dikarenakan adanya batas-batas administratif dan kewenangan yang tak mampu diatasi. Pengelolaan yang bersifat sektoral juga berpotensi tidak terintegrasinya pelayanan transpotasi antar moda yang efisien.

Oleh karena itu dituntut kelembagaan yang mampu menghadirkan Sistem Transportasi Kota yang mampu menjawab tantangan aglomerasi kota; yaitu kelembagaan yang mampu melayani pelanggan secara lintas daerah (dalam wilayah kota), dengan melibatkan antar moda transpotasi secara terpadu.

Artikel ini ditulis untuk merumuskan bentuk kelembagaan yang ideal-realistik; yang didasarkan pada hasil penelitian Tahun I; yang berusaha memahami secara detail berbagai persoalan dan tantangan praktek penyelenggaraan sistem transportasi kota di Semarang, Jakarta, Cilacap dan Yogyakarta. Serta diperkaya dengan benchmarking penyelenggaran transportasi kota yang dianggap sukses yakni Singapura (kultur melayu) dan Bogotta (aglomerasi kota negara berkembang). 


\section{KAJIAN PUSTAKA}

Konsep kelembagaan menurut Esman dan Blaise dalam Thomas dkk (1972), merupakan suatu proses sehingga kebiasaan-kebiasaan dalam bertindak serta nilainilai antar hubungan dapat mapan. Sedangkan Parsons (1966), mempergunakan terminologi institutionalization sebagai suatu integrasi menurut pengalaman para aktor dalam suatu sistem dan peran yang relevan.

Sedangkan menurut definisinya, beberapa pengertian kelembagaan dapat disajikan sebagai berikut:

a. .....aturan di dalam suatu kelompok masyarakat atau organisasi yang menfasilitasi koordinasi antar anggotanya untuk membantu mereka dengan harapan di mana setiap orang dapat bekerjasama atau berhubungan satu dengan yang lain untuk mencapai tujuan bersama yang diinginkan (Ruttan dan Hayami, 1984).

b. ....aturan dan rambu-rambu sebagai panduan yang dipakai oleh para anggota suatu organisasi (Ostrom, 1985; 1986).

c. ..... suatu himpunan atau tatanan norma-norma dan tingkah laku yang bisa berlaku dalam suatu periode tertentu untuk melayani tujuan kolektif yang akan menjadi nilai bersama. Institusi ditekankan pada norma-norma perilaku, nilai budaya dan adat istiadat (Uphoff, 1986).

d. .....mencakup penataan institusi (institutional arrangement) untuk memadukan organisasi dan institusi. Penataan institusi adalah suatu penataan hubungan antara unit-unit ekonomi yang mengatur cara unit-unit ini apakah dapat bekerjasama dan atau berkompetisi. Dalam pendekatan ini organisasi adalah suatu pertanyaan mengenai aktor atau pelaku ekonomi di mana ada kontrak atau transaksi yang dilakukan dan tujuan utama kontrak adalah mengurangi biaya transaksi (Williamson, 1985).

Berdasar beberapa definisi tentang lembaga tersebut di atas, maka dapat disimpulkan bahwa yang dimaksud dengan kelembagaan adalah suatu tatanan dan pola hubungan antara anggota masyarakat atau organisasi yang saling mengikat, yang dapat menentukan bentuk hubungan antar manusia atau antara organisasi yang 
diwadahi dalam suatu organisasi atau jaringan dan ditentukan oleh faktor-faktor pembatas \& pengikat berupa norma, kode etik, aturan formal maupun informal untuk pengendalian prilaku sosial serta insentif untuk bekerjasama dan mencapai tujuan bersama.

Haryono (2006), menulis bahwaTransportasi atau perangkutan adalah perpindahan dari suatu tempat ke tempat lain dengan menggunakan alat pengangkutan, baik yang digerakkan oleh tenaga manusia, hewan (kuda, sapi, kerbau), atau mesin. Konsep transportasi didasarkan pada adanya perjalanan (trip) antara asal (origin) dan tujuan (destination) (Haryono Sukarto:2006)

Sementara itu ada lima unsur pokok transportasi, pertama manusia, yang membutuhkan transportasi; kedua, barang yakni benda yang di diperlukan atau dikonsumsi oleh manusia; ketiga, kendaraan, yang berfungsi sebagai sarana transfer atau pemindahan manusia dan barang dari satu tempat ke tempat lain; keempat jalan, sebagai prasarana atau media transportasie serta kelima Organisasi atau kelembagaan yang bertindak sebagai pengelola transportasi.

Oleh karena itu, Sistem Transportasi terdiri dari sub sistem jaringan (sarana transportasi), subsistem pergerakan (kendaraan dan media transportasi), sub sistem Kegiatan (orang dan barang) serta sub sistem kelembagaan (organisasi). Sistem kelembagaan berfungsi mengoptimalkan ke 3 sistem di atas melalui regulasi (peraturan perundang-undangan), perencanaan, perwujudan rencana sistem transportasi dan Keuangan - Pendanaan. Jika digambarkan, secara sederhana Sistem Transportasi adalah sebagai berikut:

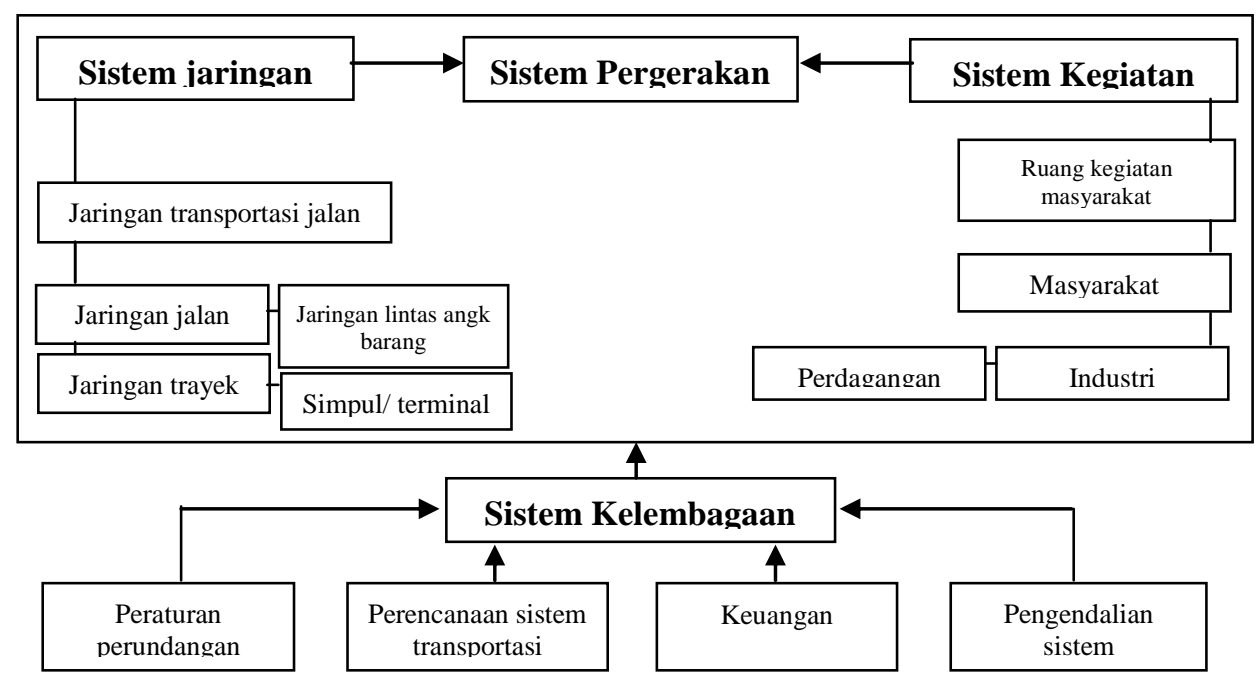


Sumber: Balitbang Kementrian Perhubungan : 2009

Konsep ketiga yang perlu di pahami adalah kota/ perkotaan; Wikipedia mencatat bahwa Kota, menurut definisi universal, adalah sebuah area urban yang berbeda dari desa ataupun kampung berdasarkan ukurannya, kepadatan penduduk, kepentingan, atau status hukum.

Wilayah kota berkembang sangat dinamis bahkan dalam beberapa kasus perkembangan kota berlangsung masif dan amat cepat. UU No 32 Tahun 2004, tentang Pemerintahan Daerah sudah mengantisipasi gejala aglomerasi dengan mendefinisikannya sebagai Kawasan Perkotaan. Dalam UU itu disebutkan bahwa Kawasan Perkotaan dibedakan atas:

1. Kawasan Perkotaan yang berstatus administratif Daerah Kota;

2. Kawasan Perkotaan yang merupakan bagian dari Daerah Kabupaten;

3. Kawasan Perkotaan Baru yang merupakan hasil pembangunan yang mengubah Kawasan Perdesaan menjadi Kawasan Perkotaan;

4. Kawasan Perkotaan yang mempunyai bagian dari dua atau lebih daerah yang berbatasan sebagai satu kesatuan sosial, ekonomi dan fisik perkotaan.

Dari pembahasan atas ke tiga konsep di atas, kelembagaan sistem transportasi perkotaan dapat dipahami sebagai Institusi yang berfungsi mengatur (meregulasi), merencanakan, mengendalikan dan melakukan sistem pergerakan barang dan orang dari satu tempat-ke tempat lain dalam satu entitas (satuan) ekonomi, sosial dan kebudayaan. Kawasan perkotaan itu sendiri akhirnya lebih dimaknai secara demografis dan sosiologis daripada secara administrasi.

Kelembagaan Sistem Transportasi kota, secara yuridis ada pada Pemerintah Kota/Kabupaten, sebagaimana diatur dalam UU No 32 tahun 2004 pasal 199 (ayat 2 dan 3) dimana dikatakan bahwa Kawasan perkotaan sebagaimana dimaksud pada ayat (1) huruf a dikelolaoleh pemerintan kota . dan Kawasan perkotaan sebagaimana dimaksud pada ayat (1) huruf b dikelola oleh daerah atau lembaga pengelola yang dibentuk dan bertanggungjawabkepada pemerintah kabupaten. Ketentuan di atas membawa implikasi besar bahwa Sistem Transportasi Perkotaan ada dibawah kewenangan Pemerintah Kabupaten / Kota. 
Selanjutnya dalam ayat berikutnya (4 dan 5) UU No 32 Tahun 2004 digariskan bahwa dalam hal kawasan perkotaan bersinggungan dengan daerah lain hal penataan ruang dan penyediaan fasilitas pelayanan umum tertentu dikelola bersama oleh daerah terkait. Pasal yang memberi payung hukum bagi dilaksanakannya kerjasama antar daerah dalam hal penataan ruang dan penyediaan fasilitas umum di daerah.

Secara Nasional, kebijakann transportasi diatur sebagaimana nampak pada gambar berikut:

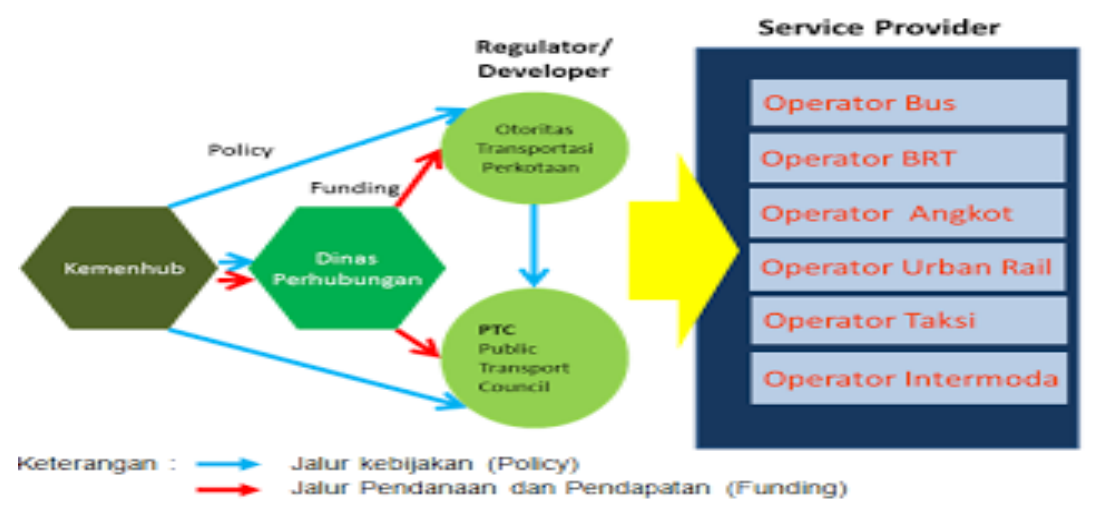

Namun demikian, secara teknis sesuai dengan UU No 32 tahun 2004, maka Kelembagaan Sistem Transportasi Kota tersebar ke dalam Dinas-dinas terkait, seperti Dinas Perhubungan Kabupaten/Kota, Dinas Pekerjaan Umum, dan Kepolisian.

Kondisi ini membawa implikasi serius :

a. Proses perencanaan, implementasi kebijakan dan evaluasi penyelenggaraan transportasi kota tersebar secara sektoral ke dalam SKPD Kota/Kabupaten.

b. Batas kewenangan regulatif kelembagaan Transportasi Perkotaan menjadi sebatas luasan wilayah Administratif Pemerintah Kabupaten/Kota;

Hal yang sama disampaikan oleh Indira (2008), bahwa salah satu kendala yang dihadapi oleh transportasi perkotaan adalah tidak jelasnya batasan wilayah pelayanan angkutan umum milik Kota dan milik Kabupaten, sehingga tumpang tindih trayek memadati ruas jalur yang sama. Kendala lain yang terkait dengan pengelolaan sistem transportasi kota adalah "terpisahnya kewenangan pengendalian lalu-lintas dan perencanaan transportasi di tiga instansi (Polantas, DLLAJ/Perhubungan dan Dinas Bina Marga); serta Kurangnya (baca:gagalnya) kordinasi antar daerah terelasi sistem transportasi kota. 
Sejalan dengan Indira dan Ditjen Hubdar di atas, temuan yang diperoleh dalam kajian kelembagaan Sistem Transportasi Perkotaan (Balitbang Kementrian Perhubungan:2009) menyimpulkan dua hal:

a. Terpisahnya kelembagaan transportasi kota ke dalam banyak SKPD, berdampak pada disharmoni dalam perencanaan, pengadaan sarana dan prasarana serta monitoring tranportasi perkotaan. Hal ini menimbulkan inefisiensi yang besar dalam sistem itu.

b. Batas kewenangan kelembagaan tranportasi perkotaan yang sama dengan batas administratif Kota/Kabupaten, berdampak pada keterbatasan pelayanan sistem tranportasi kota. Transportasi kota tidak mampu melayani warga kota yang secara administratif bergerak dari dan ke luar Kabupaten/Kota.

Untuk melakukan reformasi dan atau pengembangan kelembagaan sistem transportasi kota terpadu dan berbasis kawasan memang menghadapi tantangan berat berkait dengan euforia otonomi daerah. Otonomi daerah mengakibatkan menyempitnya wawasan perencanaan hanya pada batas-batas administratif belaka, sementara persoalan seringkali berkembang dalam besaran kawasan.

\section{METODE PENELITIAN}

Penelitian ini dilakukan dalam waktu 2 tahun. Penelitian Tahun I berfokus pada evaluasi praktek kelembagaan transportasi kota pada 4(empat) Kota, yaitu: Jakarta (kota Metropolitan), Semarang dan Yogyakarta (Kota Menengah) dan Cilacap (Kota Kecil). Penelitian Tahun II memanfaatkan Hasil penelitian tahun I dan benchmarking kelembagaan di Singapura dan Bogotta untuk menyusun model kelembagaan transportasi kota yang Ideal dan Realistik . Alur penelitian Tahun II tergambar dalam skema sebagai berikut: 


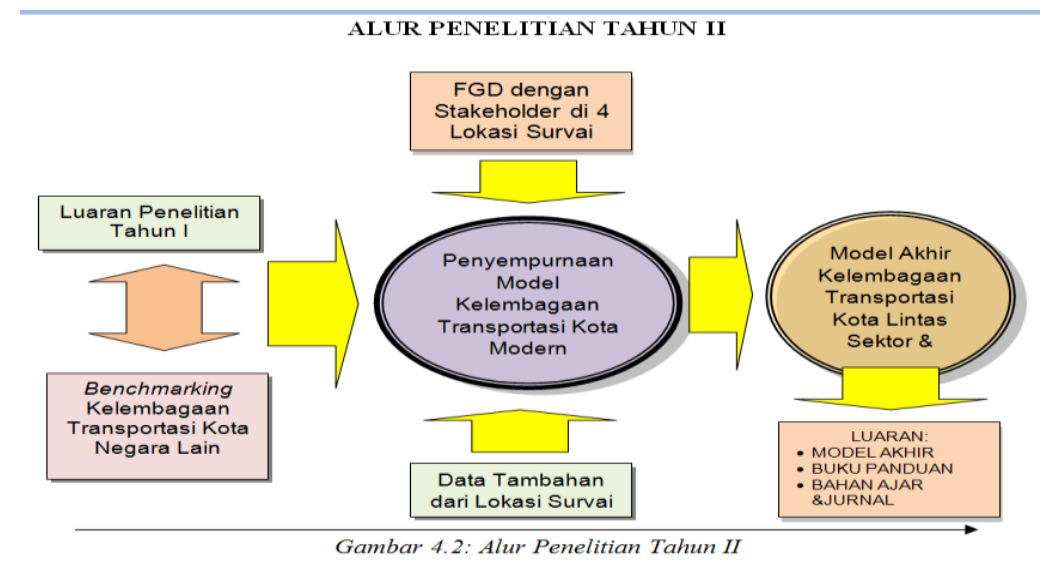

Hasil perumusan draft kelembagaan di validasi melalui diskusi dengan stakeholder . Dilengkapi dengan data akhir yang dibutuhkan, maka dapat disusun Draf akhir Kelembagaan Transportasi Kota yang diinginkan.

\section{HASIL PENELITIAN \& PEMBAHASAN}

\section{Pengalaman 4 Kota dalam Menyelenggarakan Sistem Transportasi Kota}

Berdasarkan pegalaman penyelenggaraan sistem transportasi di 4 lokasi survai, dapat dielaborasi beberapa aspek penting dalam pengembangan sistem kelembagaan transportasi kota. Karena besarnya muatan yang akan dielaborasi, maka agak sulit untuk membandingkan "apple to apple" ke empat pengalaman itu. Oleh karena itu elaborasi akan disajikan secara parsial, satu demi satu dalam aspek yang sama.

Berikut adalah temuan-temuan penting dari ke 4 lokasi survai dalam penelitian ini:

a. Setiap kota memiliki potensi, tantangan, peluang, komitmen pemerintahnya yang berbeda - beda satu sama lain. Namun demikian komitmen yang tinggi cenderung menjadi entry point dikembangkannya sistem kelembagaan transportasi kota yang kuat

b. Terdapat problem regulasi, yang sedikit banyak menjadi kendala dalam memperluas cakupan layanan sistem transportasi kota, skema pendanaan dan bentuk kelembagaan transportasi kota.

c. Hampir selalu diketemukan bahwa komitmen, dan terutama komitmen pembeayaan (dalam bentuk subsidi) menentukan keberlangsungan sistem 
transportasi kota modern. Sejauh ini tidak diketemukan sistem transportasi kota yang otonom dalam hal pembiayaannya. Dukungan Politik khususnya dari kalangan DPRD menjadi keniscayaan.

d. Pemisahan fungsi regulasi, operasi dan supervisi menjadi ciri khas yang tak dapat ditolak dalam pengembangn sistem trnsportasi kota modern.

e. Kinerja layanan yang cenderung menurun, banyak berhubungan dengan komitmen pemerintah dalam hal pendanaan.

f. BLU (Badan Layanan Umum) saat ini menjadi bentuk yang paling ideal dalam penyelenggaraan transportasi kota, karena memungkinkan kelembagaan ini lebih leluasa mengelola sistem pembeayaannya.

g. Fungsi Regulasi yang masih terpecah ke dalam banyak dinas, mengakibatkan Transportasi Kota tidak mendapat prioritas yang tinggi dalam rencana pengembangan sistem transportasi. Kordinasi antar instansi yang sulit juga menyebabkan persoalan yang dihadapi menjadi susah diurai dan diselesaikan.

\section{Pengalaman Negara Lain}

\section{SINGAPURA'S LAND TRANSPORT AUTHOROTY (LTA)}

LTA adalah gabungan berbagai unit organisasi yang sebelumnya tersebar kedalam berbagai departemen dan lembaga. Penggabungan ini menjadi strategis karena kemudian terbentuk sebuah kelembagaan besar yang berfokus kepada pengelolaan transportasi darat (Lands Transport) di Singapura, yang kuat dalam kordinasi, perencanaan yang menyeluruh dan terpadu. Kesemuanya ini menghasilkan kinerja LTA yang amat mengagumkan. Sebagaimana kita tahu LTA telah berhasil mengubah wajah Kota Besar di Asia yang tipikal sebagai kota yang padat, macet, semrawut menjadi kota dengan sistem lalu-lintas yang efisien, handal dan manusiawi.

Beberapa point strategis:

1. Penggabungan unit pengelola transportasi darat menjadi LTA tidak menimbulkan penumpukan kekuasaan, karena LTA lebih mengambil posisi sebagai regulator dan kontrol, sementara operator kereta api dan bus dikelola oleh unit operator lain yang terpisah. Pemisahan fungsi ini membawa kinerja 
yang bagus, karena LTA tidak dibebani dengan urusan operasional yang menghabiskan energy, LTA sangat hebat dalam menjalankan fungsi perencanaan partisipatif, edukasi, pengembangan sistem dan teknologi, pengaturan traffic, penetapan standard layanan, menggalang partisipasi, dan pembatasan kepemilikan dan penggunaan kendaraan pribadi. Sementara Unit operator lebih berfokus pada pelayana transportasi, peningkatan kualitas layanan dan sementara pembiayaan didapat dari LTA.

2. LTA memposisikan pelanggan (commuter and motorist) didalam jantung sistem operasi, sehingga LTA berkembang menjadi institusi yang berorientasi pelanggan.

3. Misi besar LTA adalah mengubah kebiasaan masyarakat dari penggunaan kendaraan pribadi yang boros ruang dan BBM, menjadi menggunakan angkutan publik yang jauh lebih efisien dalam dimensi ruang dan penggunaan BBM. Singapura dan LTA memeberi insentif yang besar pada warga masyarakat yang menggunakan kendaraan umum, sepeda dan pejalan kaki dengan memberikan berbagai fasilitas pendukung yang nyaman dan aman. Kepemilikan kendaraan pribadi tidak dilarang, namun penggunaannya dibatasi dengan membuat ongkos parkir yang mahal, ERP, pajak progresif, pembatasan umur kendaran pribadi, standard keselamatan yang tinggi, tollfee yang mahal dan BBM tanpa subsidi. Hasilnya, Jalan raya di Singapura menjadi nyaman dan lengang.

4. LTA sebagai sebuah otoritas, memiliki kekuasaan yang amat besar dari perencanaan, penyediaan sarana dan prasarana hingga kontrol. LTA mendapatkan dukungan penuh dari Pemerintah Singapura dengan diberi kewenangn mengelola layanan di seluruh wilayah Negara Kota Singapura. LTA bertanggungjawab lanngsung kepada Perdana Menteri.

5. Partisipasi dan edukasi kepada masyarakat pelanggan menjadi komponen penting yang harus dikerjakan. Partiipasi pelanggan dalam proses perencanaan membuat progrm peningkatan layanan menjadi lebih dekat dengan keinginan pelanggan. Sementara itu edukasi masyarakat dikerjakan untuk mempersiapkan masyarakat menjadi lebih kompatibel dengan sistem layanan 
yang secara terus menerus dikembangkan. Masyarakat yang "kompatibel" akan menjadi pelanggan yang loyal dan ramah terhadap layanan.

\section{BOGOTTA TRANSPORT SYSTEM (BTS)}

Beberapa fakta penting dari Bogotta Transport System adalah:

1. BTS adalah program transfer Pemerintah Pusat kepada enam kota yang terkait (Bogotá, Barranquilla, Bucaramanga, Cartagena, Medellin dan Pereira) berbentuk kerjasama Pemerintah pusat dengan pemerintah kota.

2. Kerja besar membangun sistem Transportasi diawali dengan reorganisasi komprehensif menuju perusahaan yang profesional dan sehat.

3. Operator dibuat terpisah dari pemerintah, disusun dalam bentuk BUMN

4. Memasukkan pembangunan infra struktur kedalam urusan "transportasi kota

5. Transmilenio (Busway) adalah backbone transportasi kota. Pilihan ini didasarkan pada pertimbangan fleksibilitas dan beaya investasi yang murah, penyediaan lahan yang efektif.

6. Sejak awal sistem sudah didesain untuk "mandiri" tidak bergantung pada subsidi sehingga tarif dibuat sesuai nilai keekonomian.

7. Kesepakatan antara 6 pemerintah kota menjadi dasar perencanaan dan pengembangan layanan.

8. Pemanfaatan Teknologi informasi untuk mendukung sistem.

9. Operator swasta/semi swasta diikat dengan konsesi. Beberapa operator adalah operator lama yang ditransformasi menjadi lembaga yang lebih modern.

10. Pemisahan tegas antara regulator dengan operator

Didukung dengan kebijakan pemerintah untuk mendorong masyarakat menggunakan transportasi publik misal: pajak gas, penggunaan kendaraan umum, pembatasan kendaraan pribadi).

\section{MODEL KELEMBAGAAN TRANPORTASI KOTA IDEAL-REALISTIK}

Berdasarkan prektek pelaksanaan Transportasi Kota di lokasi Survai (Jakarta, Semarang, Yogyakarta dan Cilacap) serta benchmarking dengan Singapura's Land Transport Authority (LTA) dan Bogotta Transport System (BTS) di dapat beberapa 
dirumuskan Model Sistem Transportasi Ideal realistik Transportasi di Indonesia sebagai berikut:

\section{Dasar Komitmen Kuat dan Perubahan Paradigma Pengelolaan Transportasi Kota.}

Membangun sistem dan kelembagaan transportasi kota harus dimulai dengan komitmen Pemerintah Daerah yang kuat; sebab kelembagaan transportasi kota yang modern dan berhasil memiliki struktur, fungsi dan tata kerja yang berbeda dengan kelembagaan tradisional. Jika selama ini infrastruktur, regulasi, pelayanan dan kontrol dilaksanakan sebagian besar oleh Pemerintah, maka kelembagaan modern biasanya memisahkan fungsi-fungsi utama itu. Demikian juga dengan struktur kelembagaannya yang secara konvensional tercerai berai kedalam banyak SKPD/Dinas Sektoral seperti Dinas Perhubungan, Dinas PU, Keamanan dan Ketertiban/Pol PP, kemudian harus gantikan oleh SKPD khusus yang menangani transportasi kota. Persoalan lain yang menjadi prasarat adalah paradigma kelembagaan transportasi kota. Jika selama ini pemerintah mengurus hampir segala hal, maka kelembagaan modern mengharuskan masuknya partisipasi swasta atau setidaknya institusi yang terpisah dengan pemerintah untuk menjadi Operator. Pemerintah dalam kelembagaan modern berfokus pada persoalan regulasi, dan monitoring/evaluasi.

\section{Struktur Kelembagaan Transportasi Kota}

Jika selama ini kelembagaan konvensional mengelola transportasi kota secara keroyokan melalui SKPD terkait (PU, Perhubungan, Ketertiban, Kepolisian, Bawasda); kelembagaan modern biasanya disusun secara terpadu. DI Singapura dibentuk Land Transport Authority dan Bogotta Transport System yang berkedudukan setingkat kementrian dengan kewenangan luas, namun berfokus pada tranpsortasi kota. Jakarta memiliki BLU yang sedang menjadi BUMD, dan terbukti kelembagaan tersebut dapat berbuat lebih cepat, komprehensif dan tidak terjebak dalam rumitnya kordinasi sektoral. Maka ke Depan di tiap kota perlu membentuk SKPD Transportasi kota, yang kewenangannya cukup kuat.

Namun dalam hal fungsi, kelembagaan modern transportasi kota perlu dipisah antara fungsi Regulasi dan Penyediaan infrastruktur dengan fungsi operasi dan 
monitoring dan evaluasi. Pemisahan ketiga fungsi ini berguna agar masing-masing lembaga fokus dengan fungsinya, dena Check and balances juga terjadi.

Berdasarkan pengalaman lokasi survai, terutama Jakarta, Semarang dan Yogyakarta, dan terutama LTA di Singapura dan Bogotta, fungsi yang dipisahkan itu antara lain:

a. Fungsi Regulasi dan Penyediaan infrastruktur.

Fungsi ini menjalankan peran penetapan kebijakan umum, penetapan standard layanan dan penyediaan infrastruktur dasar seperti thrunk line/track, shelter dan infrastruktur lain. Di Singapura regulator dijalankan oleh sebuah "dewan" atau board yang terdiri dari unsur stakeholder utama. Di Jakarta ia diwakili oleh Dinas perhubungan, dan di Yogyakarta oleh UPT TransJogja.

b. Fungsi Operasi.

Operator adalah institusi yang mengoperasikan layanan transportasi berdasarkan kebijakan yang ditetapkan oleh regulator. Operator bisa berasal dari lembaga bisnis (swasta) yang mendapatkan konsesi menjalankan operasi transportasi kota. Mereka bertanggungjawab dari pengadaan bus, mengoperasikan bus, perawatan dan menjalankan layanan sesuai standar layanan. Operator mendapatkan penghasilan berdasarkan jumlah layanan yang diberikan. Biasanya dihitung berdasarkan jumlah trayek yang dijalani, kilometr yang ditempuh dan jam pelayanan. Di lapangan, bentuk kelembagaan operator ini amat bervariasi, bisa unit bisnis yang dimiliki pemerintah (BUMD) penuh/sebagian, Badan Usaha Kerjasama Pemerintah-Swasta, atau Swasta penuh. Bogotta mentransformasi operator "lama" menjadi operator baru yang lebih modern dan berbasiskan teknologi informasi. Di Jakarta gabungan operator swasta dianggap gagal menyediakan jumlah armada yang dibutuhkan, sehingga akan diakuisisi pemerintah propinsi dan akan dibentuk kedalam sebuah BUMD yang sahamnya dimiliki pemerintah dan swasta.

c. Fungsi Monitoring dan Evaluasi (monev)

Untuk menyempurnakan sistem, monitoring dan evaluasi perlu dijalankan. Monev akan mengevaluasi apakah setiap komponen berjalan sesuai dengan rencana dan sasaran besar yang ditetapkan organisasi. Melalui monev feedback 
untuk memperbaiki kebijakan, standard layanan, infrastruktur yang diberikan dan operasi dapat diperoleh.

Idealnya unit monev berada di luar kedua lembaga yang lain; namun dalam batas tertentu, ia dapat dijalankan oleh pemerintah. Pelibatan lembaga konsumen dan asosiasi pelanggan dalam monev akan memberikan input perbaikan sistem yang positif.

Secara sederhana, struktur kelembagaan transportasi kota sebagaimana dikemukakan di atas dapat digambarkan sebagai berikut:

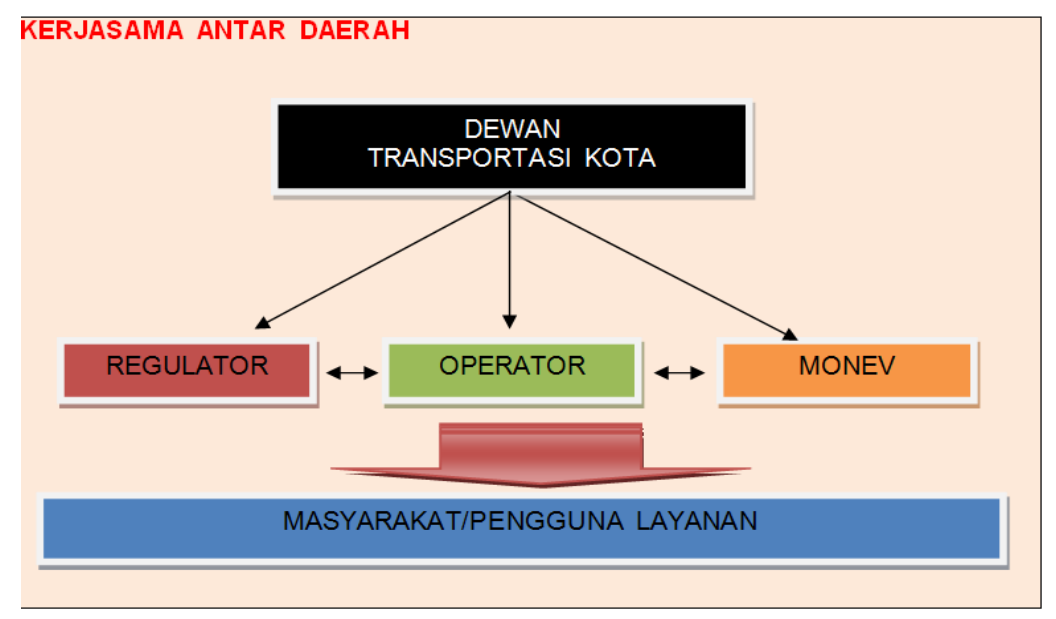

\section{Keterangan:}

\section{Dewan Transportasi Kota}

Dalam bentuknya yang lanjut, Dewan Transportasi Kota adalah Otoritas tertinggi yang bertugas merumuskan rencana besar pengembangan transportasi kota; meliputi

a. Menyerap kebutuhan masyarakat akan transportasi kota

b. kebutuhan pengembangan transportasi kota di masa mendatang;

c. perumusan Cetak Biru Pengmebangan Transportasi Kota

d. Kerjasama Operasi dengan Daerah sekitar (Daerah Penyangga)

Dewan ini beranggotakan perwakilan stakeholder utama transportasi kota, antara lain unsur Pemerintah, Unsur Operator, Unsur Konsumen dan Unsur Cendekiawan/Profesional yang perwakilannya ditentukan oleh masing-masing pihak secara demokratis. Dalam hal kebutuhan akan Dewan Transportasi Kota ini belum begitu penting (kota belum mengalami aglomerasi), maka fungsinya dapat dirangkap oleh Dinas Perhubungan/Dinas Transportasi Kota Kab/Kota setempat. Namun untuk 
kota yang sudah mengalami aglomerasi lanjut seperti Surabaya, Jakarta dan Semarang, Dewan Transportasi Kota perlu didorong untuk dibentuk.

\section{Regulator}

Unsur Regulator dalam Kelembagaan Transportasi Kota adalah otoritas pembuat kebijakan teknis transportasi kota di sebuah daerah/kota. Fungsi utama Regulator adalah menterjemahkan kebijakan yang dirumuskan Dewan Transportasi Kota menjadi :

a. Penelitian dan Pengembangan

b. Rencana Jangka Pendek Pengembangan Transportaso Kota

c. Penyediaan infrastruktur transportasi kota (Terminal, jalur/lines, shelter, ramburambu, trayek dll)

d. Perumusan Standard Layanan Transportasi Kota

e. Kontrak Operasi dengan Operator

f. Penngelolaan Keuangan Tranportasi Kota

g. Ticketting

h. Fund Rising, termasuk dengan Kerjasama Pendanaan dengan pihak ketiga

i. Komunikasi dan Edukasi pelanggan

Pada Kota yang sudah mengalami aglomerasi lanjut, maka Regulator ini dijalankan oleh SKPD khusus yang menangani Transportasi Kota (Dinas Transportasi Kota). Dalam hal belum terbentuk Dinas Transportasi Kota, maka Fungsi Regulasi dapat dijalankan oleh sebuah UPT atau Dinas Perhubungan. Yang penting fungsi-fungsi regulasi di atas dapat dijalankan.

\section{Operator}

Operator adalah institusi yang bertugas memberikan layanan secara teknis transportasi kota. Institusi ini yang mengoperasikan modalayanan transportasi kota yang dipilih. 
Secara umum Operator transportasi kota menjalankan fungsi:

a. Pengadaan armada

b. Pengoperasianarmada transportasi g. Pemeliharaan armada kota

c. Melaksanakan pelayanan

h. Memberikan panduan layanan transportasi kota pendukung

d. Memenuhi standard layanan yang ditetapkan oleh regulator

e. Menerima pembayaran layanan transportasi dari regulator

i. Mengatur headway atau waktu tunggu sesuai standard layanan yang ditentukan

j. Pengembangan sistem dan teknologi layanan transportasi

f. Mengikat kontrak layanan dengan regulator

Dalam sebuah sistem layanan transportasi kota, Unit Operator dapat terdiri lebih dari satu operator, misalnya Transportasi Berbasis Rel/rail, Bus, Perahu, subway dan moda lain; namun layanan antar operator itu diintegrasikan menjadi sebuahsistem layanan transportasi kota. Pengintegrasian layanan antar operator ini dilaksanakan oleh badan regulator transportasi kota.

\section{Monitoring dan Evaluasi}

Unit ini bertugas memastikan apakah sistem berjalan sesuai dengan rencna, apakah layanan transportasi sudah dijalankan sesuai dengan standard layanan yang dicapai.

Beberapa fungsi spesifik dari unit ini adalah:

a. Riset kepuasan pelanggan, menampung opini masyarakat pengguna layanan

b. Monitoring dan evaluasi layanan yang diberikan operator

c. Kepatuhan operator terhadap kontrak layanan

d. Mengukur kinerja layanan

Unit ini akan memberikan hasil monitoring dan evaluasi, berikut rekomendasinya kepada Dewan transportasi kota, regulator dan operator. Atas dasar itu, dewan, operator dan regulator dapat melakukan tindakan perbaikan berdasarkan feedback unit Monev ini. Pemerintah daerah dapat membentuk unit monev ini, atau 
melekatkannya kepada sebagian unit di Dinas Perhubungan. Dalam konsep paling akhir, unit ini berisi para profesional/auditor yang menguasai metodologi assessment transportasi kota. Dengan begitu hasil monev dapat dipertanggungjawabkan validitasnya.

\section{Skema Pendanaan}

Persoalan paling krusial dalam penyelenggaraan sistem transportasi kota yang modern adalah persoalan pendanaan. Tidak jarang sistem yang dirancang baik, gagal berlanjut (sutainable) karena tidak didukung pendanaan yang memadai (lihat kasus Trans Jogja, dan Trans-Jakarta sebelum pemerintahan Jokowi-Ahok). Pembiayaan infrastruktur membutuhkan pembeyaan yang besar. Sementara itu harga layanan secara keekonomian (harga pasar) tidak terjangkau oleh sebagian besar pengguna layanan. Oleh karena itu subsidi layanan public (Public Service Obligation) tidak terelakkan.

Subsidi layana publik (PSO) dibidang transportasi kota memiliki pijakan yang kuat mengingat manfaat ini:

a. Keuntungan ekonomis yang timbul dari terurainya kemacetan lalulintas dari yang biasanya diderita oleh sebuah kota.

b. berkurangnya beban subsidi BBM sebagai akibat menurunnya konsumsi BBM kendaraan pribadi dan time opportunity cost yang terselamatkan karena lalulintas yang lancar.

Namun karena besaran PSO ini ditetapkan dalam bentuk subsidi dalam APBD, maka subsidi ini perlu ditetapkan untuk jangka waktu yang cukup untuk menjaga stabilitas dan kontinuitas layanan. Jika tidak, maka kasus Trans Jogja akan selalu terulang, dimana ketidakpastian PSO menyebabkan operator enggan meningkatkan investasinya

Pengalaman Bogotta, Jakarta, Yogyakarta dan Semarang menunjukkan terwujudnya transportasi kota diawali dengan dialokasikannya dana pemerintah dalam bentuk "transfer" kepada sistem transportasi kota. Transfer ini kemudian dapat dihitung sebagai penyertaan modal pemerintah dalam perusahaan operator transportai kota. 
Namun Kasus Bogotta menjadi menarik, karena sejak awal sistem ini didesain tanpa subsidi; harga layanan kemudian ditetapkan dengan harga keekonomian $(0,79$ US Dollar), agar pemerintah tidak perlu mensubsidi operator. Perancang Bogotta Tansport System berkeyakinan bahwa sistem yang sehat dan sutainable hanya mungkin jika sistem itu bisa berjalan tanpa subsidi dan bantuan pihak manapun. Terbukti masyarakat tetap antusias menggunakan Trans Millenia, karena kualitas layanannya yang bagus, dan dukungan kebijakan yang memadai.

Untuk kasus Transportasi Kota di Indonesia, PSO adalah pilihan yang terbaik, karena Pemerintah yang dipilih secara elektoral tidak mungkin mengambil keputusan yang tidak populer dengan tidak memberikan subsidi pada layanan transportasi kota. Namun begitu, PSO sebagai subsidi hendaklah tidak bersifat permanen.

\section{Unit Bisnis Yang Sehat}

Operator sebagai kelembagaan inti dalam layanan transportasi kota hendaknya merupakan unit bisnis yang sehat. Ia Harus efisien, profesional, handal dan memiliki margin keuntungan cukup untuk berkembang. Sebab tanpa itu semua, maka layanan transportasi kota akan stagnan dan cenderung menurun layanannya.

Bogotta dan Singapura mentransformasi operator lama yang kurang sehat menjadi institusi bisnis modern yang sehat. Karena transportasi kota adalah bisnis yang padat modal, maka operator-operator kecil diminta bergabung menjadi sebuah konsorsium yang menjalankan fungsi operasi. Persaingan antar operator perlu dihidupkan untuk selalu mendorong mereka semakin efisien. Namun lebih dari itu, mereka harus memiliki margin keuntungan yang cukup untuk berkembang. Jalan keluarnya adalah Subsidi operasi (PSO) atau menetapkan harga keekonomian. Jika PSO menjadi jalan keluar, maka perlu dibuat skema agar pada titik tertentu, subsidi terebut dapat mencapai titik nol (tanpa subsidi). Namun untuk kondisi seperti Jakarta, dimana kemacetan sudah amat parah, dan daya beli masyarakat sudah cukup baik, maka penetapan harga layanan secara keekonomian memiliki peluang untuk direalisasi. Tentu perlu dukungan kebijakan lain agar pasar tetap gemuk, dengan pembatasan kendaraan pribadi melalui electronic road pricing, Pencabutan BBM 
kendaraan pribadi, Three in one, pembatasan sepeda motor, tarif parking yang tinggi dan kebijakan lain yang mampu mendorong pengguna tetap memilih transportasi kota yang massal, cepat dan baik.

\section{Kerjasama antar Daerah.}

Tidak dapat disangkal, aglomerasi kota mengakibatkan besaran fisik kota melintasi batas teritori daerah. Jakarta sebagai metropolitan sudah melimpas kewilayah sekitarnya, Jogjakarta, Semarang dan kota-kota besar lain sudah tumbuh melintas daerah sekitarnya. Padahal, batas layanan seringkali dibatasi oleh batasan administratif.

Yogyakarta beruntung karena sekaligus menjadi Ibukota Propinsi, sehingga inisiatif penyelenggaraan TransJogja diambil alih oleh Dinas Perhubungan Propinsi. Ini menyebabkan cakupan layanan TransJogja bisa melintas batas administratif kota. Namun tidak semua kota seberuntung Yogyakarta. Sehingga jalan keluar yang realistis adalah membuat kerjasama antar daerah (yang payung hukumnya sudah tersedia), untuk memayungi penyelenggaraan transportasi kota lintas wilayah.Kesepakatan kerjasama itu dapat menjadi landasan dibentuknya kerjasama operasi atau penggabungan sistem transporrtasi kota antar daerah.

Pemerintah DKI misalnya sedang sangat intensif bekerjasama menyatukan layanan transportasi kota dengan Bogor, Bekasi dan Tangerang. Jika kerjasama tersebut terealisasi, maka warga Jakarta yang tinggal di wilayah Tangerang, bekasi atau Bogor dapat menggunakan layanan transportasi yang terintegrasi dengan TransJakarta. Mereka cukup sekali bayar untuk mencapai tujuan perjalanannya. Mengintegrasikan dua atau lebih sistem transportasi kota secara terpadu memang tidaklah mudah, karena ini menyangkut transaksi keuangan, pembagian pendapatan, investasi dan kompatibilitas layanan. Oleh karena itu pemanfaatan teknologi informasi dan sistem perbankan membuat gagasan besar itu dapat diwujudkan.

\section{Komunikasi dan Edukasi Pelanggan}

Perubahan kelembagaan transportasi kota seringkali menuntut perubahan prosedur layanan, standard layanan, hingga perilaku pengguna layanan. Konsumen 
bus kota yang terbiasa dengan penghentian di mana saja dia kehendaki, jelas akan merasa kerepotan manakala harus beralih pada layanan berbasis shelter. E-ticketting menuntut tambahhan prasarat bagi pelanggan karena mereka harus memiliki akun, deposit dana, dan melek teknologi. Demikian juga dengan informasi yang mendukung harus diakses pelanggan secara mandiri, sehingga membutuhkan ketrampilan pelanggan mendapatkan informasi. Kesemua ini menuntut perubahan pengetahuan, sikap dan perilaku yang kompatibel dengan model layanan yang disediakan. Dalam konteks demikian, maka harus ada kelembagaan yang menangani fungsi edukasi pelanggan, agar pengetahuan, sikap dan perilaku pelanggan sesuai dengan sistem layanan.

Beberapa langkah mengedukasi pelanggan yang harus dilakukan, antara lain:

a. Memberikan informasi tentang program, promo, kemudahan layanan untuk pelanggan secara berkala. Hal tersebut dapat dilakukan melalui pengiriman email, SMS, brosur, papan reklame dan lain-lain kepada masyarakat

b. Mengadakan acara atau pertemuan antara regulator, operator layanan transportasi kota dengan pelanggan potensial misalnya: pelajar, mahasiswa atau karyawan.

c. Meminta masukan dari pelanggan potensial dan testimonial sebagai saran untuk membantu meningkatkan layanan transportasi kota. Dalam hal ini Layanan trnsportasi kota harus memiliki kemampuan untuk mengidentifikasikan dan mengatasi permasalahan pelanggan atau masyarakat. Penyedia jasa layanan transportasi kota harus bersifat " customer drive " yang selalu berupaya untuk mengidentifikasikan dan mengatasi permasalah pelanggan.

d. Komunikasi dengan pelanggan dilakukan secara teratur.

Selain komunikasi dengan pelanggan jasa layanan transportasi kota juga perlu melakukan edukasi /pendidikan kepada pelanggan. 


\section{Hibah Daerah \& PSO untuk Pembentukan Sistem Transportasi Kota Modern}

Secara teoritik, semakin kecil ketergantungan sebuah sistem terhadap kekuatan diluarnya, akan semakin besar peluang sistem itu berlanjut (sustainable) . Demikian juga dengan sistem kelembagaan transportasi kota; semakin kecil ketergantungannya kepada pihak lain, maka keberlangungannya semakin besar.

Namun demikian, realitas dalam dunia transportasi kota tidaklah demikian. Kelembagaan transportasi kota modern harus bersaing dengan sistem lama yang sudah mapan dan efisien dalam operasinya; padahal tanpa keunggulan kompetitif, maka sistem baru akan tidak diminati pengguna layanan. Orang misalnya tidak akan mau beralih menggunakan busway dari metromini, jika busway tidak memberi keuntungan yang lebih besar kepada mereka. Salah satu faktor penting yang diperhatikan pelanggan adalah beaya layanan.

Dalam keadaan belum efisien, dengan standard layanan lebih baik dari moda transportasi kota konvensional, maka mustahil sistem baru akan diminati pelanggan. Jalan keluar yang paling logis adalah memberi sistem baru itu dengan subsidi, agar mereka kompetitif dengan beaya layanan. Dalam dunia layanan publik dikenal dengan Public Service Obligation (PSO), yakni subsidi pemerintah terhadap layanan yang diberikan. PSO ini bisa berupa subsidi tiket atau subsidi operasional pada operator. Sehingga subsidi menjadi kata kunci bagi keberlangsungan layanan.

Pemerintah Kab/Kota harus bisa menerbitkan Peraturan Daerah yang menjamin kepastian. subsidi bagi transportasi kota modern. Besaran subsidi yang ditetapkan secara insidental atau tahunan (seperti kasus Trans Jogja) sering menjadi hambatan operator untuk menghitung beaya layanan yang ditetapkan, karena subsidi menjadi variabel yang tidak pasti.

Pemerintah Pusat dapat membantu Pemerintah Kabupaten/Kota dengan semacam Hibah Daerah untuk transportasi kota. Hibah bisa diberikan secara kompetitif untuk daerah yang daianggap sukses menyelenggarakan sistem layanan tranpsortasi kota yang baik. 


\section{DAFTAR PUSTAKA}

Aufarul Marom, (2003); Kualitas Pelayanan Transportasi Kota Semarang; (Tesis); Pasca Sarjana UGM; Yogyakarta

Balitbang Kementrian Perhubungan (2009); Kajian Kelembagaan dan Keuangan Transportasi Kota di Indonesia.; Jakarta

Bappenas; (2010) Visi Misi Transportasi,

http://transportasi.bappenas.go.id (last accesed 18/04/2010

Barret Richard; (1983), Institution Building for traffic Management, World Bank technical paper No 8 (Urban Development Technical Paper) World Bank, Washington

Ciptaningrum, Dyah; (2008) “Aspek Hukum Bentuk Kelembagaan Badan Pengelola Trans-Jakarta Busway Berbasis Transportasi”, Disertasi, ((http://garuda.kemdiknas.go.id/jurnal/detil/id/90:2771/q/kelembagaan\%20tran sportasi\%20kota/offset/0/limit/15)

Direktorat Perhubungan Darat, (2008) Sistem Transportasi Kota, , Direktorat Bina sistem Lalu Lintas dan angkutan kota.), BSLLAK

Fidel Miro SE., MSTr., (2006) ITS Surabaya, Jurnal Teknik Sipil, Vol. 3 , No. 2, Juli 2006

Haryono Sukarto(2005) Transportasi Perkotaan dan Lingkungan sukarto@yahoo.com )Jurusan Teknik Sipil - Universitas Pelita Harapan UPH Tower, Lippo Karawaci, Tangerang 15811, Banten

Indira Intan Latif (2008); Pengelolaan Sistem Transportasi Kota Bogor dalam Mengatasi Kemacetan; Program Magister Manajemen Pembangunan Kota, ITS Surabaya.

Ruswanto, Wawan (2009); Kelembagaan Transportasi Kota Medan;Jurnal On line pada Portal Garuda Kemendiknas; Disertasi Universitas Indonesia (http://garuda.kemdiknas.go.id/jurnal/detil/id/90:12487/q/transportasi\%20kota $\% 20$ medan/offset/0/limit/15)

Bisnis.com ; 14 Maret 2013

Bisnis.com;Emanuel Tome Hayon, Transjakarta Harus Secepatnya Jadi BUMDKamis, 21 Maret 2013, 20:00 WIB

http://id.wikipedia.org/wiki/Kabupaten_Cilacap\#Transportasi

http://www.cilacapkab.go.id/v2/index.php?pilih=hal\&id=56 
Kompas.com; B ima Setiadi, 12 Juni 2012 "Buslane Siap Beroperasi”

Kompas.com; B ima Setiadi, 13 Juni 2012 "Tiket Buslane Rp 6.500, Bisa Lanjut Transjakarta"

liputan6.com/tag/transjakarta/?channel=news; Berita Harian Transjakarta Kumpulan Berita Transjakarta Terbaru

NograhanyWidhi K; detikNews.com; Balada Bus Rapid Transit: Didamba Penumpang, Ditentang Sopir Angkot; Kamis, 03/05/2012 14:53 WIB

www.merdeka.comKUMPULAN BERITA TRANSJAKARTA : Pemprov DKI berencana ...

www.transjakarta.co.id :: Unit Pengelola Transjakarta Busway 